\title{
UDC 539.4:624.01
}

\section{SPATIAL PROBLEMS OF DYNAMIC STABILITY OF FRAME STRUCTURES}

\author{
V. Fomin ${ }^{1}$, I. Fomina ${ }^{1}$ \\ ${ }^{I}$ Odessa State Academy of Civil Engineering and Architecture
}

\begin{abstract}
Periodic longitudinal forces in structural elements caused by operational or seismic influences, at certain values of the parameters of these forces can cause the occurrence and growing of transverse oscillations of these elements. This phenomenon is called parametric resonance or loss of dynamic stability. In the works of N. M. Belyaev, N. M. Krylov, M. M. Bogolyubov, E. Mettler, V. N. Chelomey, V. V. Bolotin flat problems of dynamic stability of frame structures were investigated. In this paper the modified Bolotin's method, proposed to solve flat problems of dynamic stability of frames, is used. Instead of the deformation method used by V. V. Bolotin to construct analytical expressions of deflections of frame rods, in the modified method the numerical-analytical method of boundary elements is used. The article proposes a method for constructing domains of dynamic instability of frames in the space of parameters (frequency and amplitude) of seismic and operational dynamic influences that cause longitudinal forces in the rods, which periodically change over time and lead to unlimited growth of transverse oscillations amplitudes in the domains of instability. The proposed method is demonstrated in example, which considers the spatial problem of dynamic stability of a П-shaped frame with two concentrated masses located on it, which are under the action of vertical periodic forces. These forces create periodic longitudinal forces in the vertical rods of the frame. Areas of dynamic instability of the frame were constructed.

Taking into account the destructive effect of oscillations is important for practical application. The most dangerous destructive effect of oscillations is observed in earthquakes and explosions. The study of this action makes it possible to avoid undesirable consequences of oscillations by limiting their level and to solve important practical problems of the dynamics of structures. Solving dynamics problems is a difficult problem. Dynamic calculation of structures provides their bearing capacity under the combined action of static and dynamic loads.
\end{abstract}

Keywords: reinforced concrete frames, dynamic instability, domains of instability.

\section{ПРОСТОРОВІ ЗАДАЧІ ДИНАМІЧНОЇ СТАБІЛЬНОСТІ КАРКАСНИХ КОНСТРУКЦЙ}

\author{
Фомін В. М. ${ }^{1}$, Фоміна I. П. ${ }^{1}$ \\ ${ }^{\text {I} О д е с ь к а ~ д е р ж а в н а ~ а к а д е м і я ~ б у д і в н и ц т в а ~ т а ~ а р х і т е к т у р и ~}$
}

Анотація: Періодичні поздовжні сили в елементах конструкцій, викликані експлуатаційними або сейсмічними впливами, при певних значеннях параметрів цих сил можуть викликати виникнення і зростання поперечних коливань цих елементів. Це явище називається параметричним резонансом або втратою динамічної стійкості. У працях Н. М. Бєляєва, Н. М. Крилова, М. М. Боголюбова, Є. Меттлера, В. Н. Челомея, В. В. Болотіна досліджено плоскі проблеми динамічної стійкості каркасних конструкцій. У даній роботі використано модифікований метод Болотіна, запропонований для вирішення плоских задач динамічної стійкості фреймів. Замість методу деформації, використаного В. В. Болотіним для побудови аналітичних виразів прогинів стержнів каркаса, у модифікованому методі використовується чисельно - аналітичний метод граничних елементів. У статті запропоновано метод побудови областей динамічної нестійкості каркасів у просторі параметрів (частоти та амплітуди) сейсмічних та експлуатаційних динамічних впливів, що викликають поздовжні сили в стрижнях, які періодично змінюються 3 часом і приводять до необмеженого зростання поперечних коливань. амплітуди в областях нестійкості. Запропонований метод 
продемонстровано на прикладі, який розглядає просторову задачу динамічної стійкості П-подібної рами з розташованими на ній двома зосередженими масами, які перебувають під дією вертикальних періодичних сил. Ці сили створюють періодичні поздовжні сили у вертикальних стрижнях рами. Побудовано ділянки динамічної нестійкості каркаса.

Урахування руйнівної дії коливань має важливе значення для практичного застосування. Найбільш небезпечна руйнівна дія коливань спостерігається при землетрусах та вибухах. Дослідження цієї дії дає можливість уникнути небажаних наслідків коливань шляхом обмеження їх рівня та вирішити важливі практичні проблеми динаміки споруд. Розв'язання задач динаміки є складною проблемою. Динамічний розрахунок споруд забезпечує їх несучою здатністю при спільній дії статичних та динамічних навантажень.

Ключові слова: залізобетонні каркаси, динамічна нестійкість, області нестійкості. 


\section{INTRODUCTION}

The problem of studying the dynamic stability of building structures is actual due to the fact that the load transmitted through the floors from the equipment or through the crane beams to the columns of the industrial building frames is mainly harmonic in nature, as a result of which harmonic longitudinal forces arise in the construction columns. At certain values of the amplitudes and frequencies of these forces, this can lead to the emergence and buildup of trans-verse vibrations of the vertical rods of structures, and, therefore, to the possibility of their de-struction.

\section{ANALYSIS OF LITERATURE DATA AND PROBLEM STATEMENT}

The first work in the field of structure dynamic stability investigation was published by N. M. Belyaev in 1924 [1]. It raised and solved the problem of dynamic stability of a rod supported by hinges at its ends, i.e. the conditions for the appearance and rise of the rod transverse vibrations under the action of a periodic longitudinal force were investigated. It was shown that the values of the frequency and amplitude of the longitudinal force, at which an unlimited in-crease in the amplitude of the rod transverse vibrations is observed, form continuous regions in the space of these parameters, which are called instability domains. In 1935 N. M. Krilov and N. N. Bogolyubov [2], and E. Mettler [3] in 1940 continued research by N. M. Belyaev, having investigated the problem of the rod dynamic stability with arbitrary fixing at its ends. In the book of V. N. Chelomei [4], published in 1939, the problems of dynamic stability for rods of variable cross-section, for rods with initial deflection, and also for multi-span rods were considered. In 1953-1956 V. V. Bolotin [5,6] published a number of works devoted to the dynamic stability of rods, beams and frames. At the Kiev National University of Civil Engineering and Architecture, Bolotin's research in this area was continued [7-8].

It should be noted that in the above works, plane problems of dynamic stability of frames were investigated. In the work of N. A. Nikolaenko and Yu. P. Nazarov [9], the spatial problem of dynamic stability of a frame structure model, consisting of absolutely solid horizontal plates (modeling intermediate floors) connected by a system of geometrically nonlinear vertical rods was solved. However, for longterm structures, this model becomes not enough accurate. Therefore, in this work, to study the spatial problem of the dynamic stability of a frame structure, a model is adopted in the form of a mechanical system consisting of a weightless frame and concentrated masses located at its nodes (note that this type of model is used when calculating structures for seismic effects), and modified Bolotin's method, proposed in [5] for solving plane problems of frame dynamic stability, is used. Moreover, instead of the deformation method used by V. V. Bolotin to construct analytical expressions for frame rod deflections, the numerical-analytical boundary elements method is used [10].

\section{PURPOSE AND OBJECTIVES OF THE RESEARCH}

The aim of this work is to study the spatial problem of dynamic stability of structures using a model of a structure in the form of a mechanical system consisting of a weightless frame and concentrated masses located in its nodes (note that this type of model is used in normative calculation of structures for seismic effects). 


\section{RESEARCH RESULTS}

In this paper the modified method by V. V. Bolotin, is used, which was proposed in [5] to solve flat problems of dynamic stability of frames. In this case, instead of the method of deformation used by V. V. Bolotin to construct analytical expressions of deflections of frame rods, the numerical-analytical method of boundary elements is used [10]. Let's number the frame rods and enter on each of the rods a local rectangular coordinate system $x_{k}, y_{k}, z_{k}(k-$ rod number, axis $x_{k}$ is directed along the axis of the rod). In addition, we introduce the global abscissa $s$ of the frame points as follows: $s=x_{1}$ for the points of the axis of the first rod, $s=\sum_{\mathrm{j}=1}^{k-1} l_{j}+x_{k}$ for points of the axis of the rod with the number $k>1\left(l_{j}-\right.$ the length of the $j$-th rod). We will find dynamic deflections of rods of a frame in the following form:

$$
\boldsymbol{v}(s, t)=\sum_{i=1}^{n} w_{i}(t) \mathbf{\Phi}_{i}(s) \text {. }
$$

$n$ - the number of degrees of freedom of the abovementioned mechanical system. Here, in contrast to [5] $\boldsymbol{v}(s, t)$ is not a scalar function, but a vector:

$$
\boldsymbol{v}(s, t)=\left[\begin{array}{l}
v_{y}(s, t) \\
v_{z}(s, t) \\
\Theta(s, t)
\end{array}\right],
$$

$v_{y}$ - deflection of the rod at a point with abscissa $\mathrm{s}$ in the direction of the $\mathrm{y}$-axis of the local coordinate system, $v_{z}$ - in the z-axis direction of this system, $\Theta$ - the angle of rotation of the cross section), $w_{i}(t)$ are scalar functions, $\boldsymbol{\Phi}_{i}(s)$ are three-dimensional vector functions:

$$
\Phi_{i}(s)=\left[\begin{array}{c}
\Phi_{i, 1}(s) \\
\Phi_{i, 2}(s) \\
\Phi_{i, 3}(s)
\end{array}\right] .
$$

In [5] it is stated that as $\Phi_{i}(s)(i=1,2, \ldots, \mathrm{n})$ we can take functions with the help of linear combinations of which we can approximate the forms of free vibrations of the structure. In particular, you can use the functions of deflections of the frame from the action of forces $F_{i}$ $\left(F_{i}=1 \kappa H, i=1,2, \ldots, n\right)$, applied to concentrated masses. Considering $w_{i}(t)$ as generalized coordinates, we compose the Lagrange equation for this problem

$$
\frac{d}{d t}\left(\frac{\partial T}{\partial w_{i}}\right)+\frac{\partial}{\partial w_{i}}(U-T)=Q_{i} \quad(i=1,2, \ldots, n),
$$

where $T$ and $U$ are kinetic and potential energy of the frame with a system of concentrated masses located on it, $Q_{i}$ are generalized forces.

The kinetic energy of the system is equal to the sum of the kinetic energies of the concentrated masses: 


$$
\left.T(t)=\frac{1}{2} \sum_{j=1}^{r} m_{j}\left[v_{y}^{2}\left(s_{j}, t\right)\right)+v_{z}^{2}\left(s_{j}, t\right)\right],
$$

( $r$ is the quantity of concentrated masses). Taking into account formulas (1) - (3) we obtain

$$
\frac{\partial T}{\partial w_{i}}=\sum_{j=1}^{r} m_{j}\left[\Phi_{i, 1}\left(s_{j}\right) \sum_{k=1}^{n} w_{k}(t) \Phi_{k, 1}\left(s_{j}\right)+\Phi_{i, 2}\left(s_{j}\right) \sum_{k=1}^{n} w_{k}(t) \Phi_{k, 2}\left(s_{j}\right)\right](i=1,2, \ldots, n) .
$$

Changing the order of summation by $j$ and $k$, we obtain

$$
\frac{\partial T}{\partial w_{i}}=\sum_{k=1}^{n} f_{i k} w_{k}(t)
$$

where

$$
f_{i k}=\sum_{j=1}^{r} m_{j}\left[\Phi_{i, 1}\left(s_{j}\right) \Phi_{k, 1}\left(s_{j}\right)+\Phi_{i, 2}\left(s_{j}\right) \Phi_{k, 2}\left(s_{j}\right)\right] .
$$

The potential energy of each of the frame rods consists of the potential bending energies of the rod in the planes $x y$ and $x z$ of the local coordinate system and the potential energy of rotation around the axis of the rod. Therefore, the potential energy of the frame is determined from the ratio

$$
U(t)=\frac{1}{2}\left\{\int_{0}^{L} E(s) J_{z}(s)\left[v_{y}^{\prime \prime}(s, t)\right]^{2} d s+\int_{0}^{L} E(s) J_{y}(s)\left[v_{z}^{\prime \prime}(s, t)\right]^{2} d s+\int_{0}^{L} G(s) J_{p}(s)\left[\Theta^{\prime}(s, t)\right]^{2} d s\right\} .
$$

Here the stroke means a derivative by $s, J_{p}(s)$ is the polar moment of inertia of the cross section relative to the center of intersection, $E(s)$ and $G(s)$ are the moduli of elasticity and shearing of the material of the frame rods, $L$ is the total length of the frame rods. After substituting the relationship (1) into (8) and differentiation by $w_{i}$ we get

$$
\frac{\partial U}{\partial w_{i}}=\sum_{k=1}^{n} r_{i, k} w_{k}(t)
$$

where

$$
\begin{aligned}
& r_{i, k}=\int_{0}^{L} E(s) J_{z}(s) \Phi_{\mathbf{i}, 1}^{\prime \prime}(s) \Phi_{k, 1}^{\prime \prime}(s) d s+\int_{0}^{L} E(s) J_{y}(s) \Phi_{\mathbf{i}, 2}^{\prime \prime}(s) \Phi_{k, 2}^{\prime \prime}(s) d s+ \\
& +\int_{0}^{L} G(s) J_{p}(s) \Phi_{i, 3}^{\prime}(s) \Phi_{k, 3}^{\prime}(s) d s .
\end{aligned}
$$

The work of the external distributed transverse load is determined as follows:

$$
V=\int_{0}^{L}\left[q_{y}(s, t) v_{y}(s, t)+q_{z}(s, t) v_{z}(s, t)\right] d s
$$

$\left(q_{y}, q_{z}, v_{y}, v_{z}\right.$ are components of loads and deflections of rods in the corresponding local coordinate systems). Generalized forces can be found from the relations $Q_{i}=\partial V / \partial w_{i}$ $(i=1,2, \ldots, n)$. From $(1)$ it follows that

$$
Q_{i}(t)=\int_{0}^{L}\left[q_{y}(s, t) \Phi_{i, 1}(s)+q_{z}(s, t) \Phi_{i, 2}(s)\right] d s(i=1,2, \ldots, n) .
$$


Making in (11) integration by parts, we obtain

$$
Q_{i}(t)=-\int_{0}^{L}\left[Q_{y}(s, t) \frac{\partial \Phi_{i, 1}(s)}{\partial s}+Q_{z}(s, t) \frac{\partial \Phi_{i, 2}(s)}{\partial s}\right] d s(i=1,2, \ldots, n) .
$$

Here $Q_{y}(s, t)$ and $Q_{z}(s, t)$ are components of the transverse force in the cross sections of the rods.

We limit ourselves by solving problems of dynamic stability under the action of vertical variable forces applied to concentrated masses. The influence of the longitudinal forces that arise in the rods of the frame on their bending deformation is taken into account by the ratio [5].

$$
Q_{y}(s, t)=-N(s, t) v_{y}^{\prime}(s), Q_{z}(s, t)=-N(s, t) v_{z}^{\prime}(s) .
$$

We consider the case when the forces acting on concentrated masses change synchronously by time

$$
P_{j}(t)=(\alpha+\beta \cos \psi t) P_{0, j}(j=1,2, \ldots, r),
$$

( $\alpha$ and $\beta$ are positive scalar parameters). It is assumed that $\alpha$ is less than the critical value, i.e. that the structure under the action of static forces $\alpha P_{0, j}(j=1,2, \ldots, r)$ is in a position of stable equilibrium. From (13) it follows that for the longitudinal forces in the rods of the frame there is the following relationship:

$$
N(s, t)=(\alpha+\beta \cos \psi t) N_{0}(s),
$$

where $N_{0}(s)$ is the system of longitudinal forces in the rods of the frame caused by forces $P_{0, j}(j=1,2, \ldots, r)$.

It follows from (13) and (14), that

$$
Q_{i}(t)=(\alpha+\beta \cos \psi t) \int_{0}^{L} N_{0}(s)\left[v_{y}^{\prime}(s) \Phi_{i, 1}^{\prime}(s)+v_{z}^{\prime}(s) \Phi_{i, 2}^{\prime}(s)\right] d s(i=1,2, \ldots, n) .
$$

Using the expansion (1), we obtain

$$
\begin{aligned}
& Q_{i}(t)=(\alpha+\beta \cos \psi t) \sum_{k=1}^{n} s_{i k} w_{k}(t) \quad(i=1,2, \ldots, n), \\
& s_{i k}=\int_{0}^{L} N_{0}(s)\left[\Phi_{i, 1}^{\prime}(s) \Phi_{k, 1}^{\prime}(s)+\Phi_{i, 2}^{\prime}(s) \Phi_{k, 2}^{\prime}(s)\right] d s(i, k=1,2, \ldots, n) .
\end{aligned}
$$

Substitution of (7), (10) and (15) into the Lagrange equation (4) leads to a system of differential equations

$$
\sum_{k=1}^{n} f_{i k} \ddot{w}_{k}(t)+\sum_{k=1}^{n}\left[r_{i k}-(\alpha+\beta \cos \psi t) s_{i k}\right] w_{k}(t)=0(i=1,2, \ldots, n),
$$

which in matrix form can be written as follows:

$$
\boldsymbol{F} \ddot{\boldsymbol{w}}+[\boldsymbol{R}-(\alpha+\beta \cos \psi t) \boldsymbol{S}] \boldsymbol{w}=0 .
$$

If $\beta=0$, i.e. when forces $P_{j}(j=1,2, \ldots, r)$ are constant, the system of equations (18) in this case

$$
\boldsymbol{F} \ddot{\boldsymbol{w}}+[\boldsymbol{R}-\alpha \boldsymbol{S}] \boldsymbol{w}=0,
$$


determines the free vibrations of the frame, the rods of which are loaded with longitudinal constant forces. Substitution $\boldsymbol{w}=\boldsymbol{W} \sin \Omega t$ into (18) allows us to construct the equation of frequencies of free vibrations of such a frame:

$$
\operatorname{det}\left(\boldsymbol{R}-\alpha \boldsymbol{S}-\Omega^{2} \boldsymbol{F}\right)=0
$$

To study the dynamic stability of the structure, it is necessary to use a system of differential equations (17) with coefficients that periodically depend on time. By multiplying this system by $\boldsymbol{R}^{-1}$, we bring it to the following form:

$$
\boldsymbol{C} \ddot{w}+[\boldsymbol{E}-(\alpha+\beta \cos \psi t) \boldsymbol{A}] \boldsymbol{w}=0 .
$$

Here $\boldsymbol{C}=\boldsymbol{R}^{-1} \boldsymbol{F}, \boldsymbol{A}=\boldsymbol{R}^{-1} \boldsymbol{S}, \boldsymbol{E}$ is the unit matrix. The boundaries of the main domains of instability in the first approximation are determined from equality [5]

$$
\operatorname{det}\left[\boldsymbol{E}-\left(\alpha \pm \frac{1}{2} \beta\right) \boldsymbol{A}-\frac{1}{4} \psi^{2} \boldsymbol{C}\right]=0 \text {. }
$$

Note that in [5] the main domains of instability are areas in the plane of parameters $\beta, \psi$ (at a fixed value $\alpha$ ), boundaries of which at $\beta=0$ converge at points $\psi_{k}=2 \Omega_{k}\left(\Omega_{k}\right.$ is one of the frequencies of free vibrations of the frame loaded by constant longitudinal forces. In (21) the plus sign corresponds to the lower boundary of the area, and the minus sign - to the upper one.

We will demonstrate the proposed technique on a specific example.

Example. The spatial problem of dynamic stability of a П-shaped frame with two masses $M_{1}$ and $M_{2}$ under the action of two vertical forces $P_{1}(t)$ and $P_{2}(t)$ is considered (Fig.1).

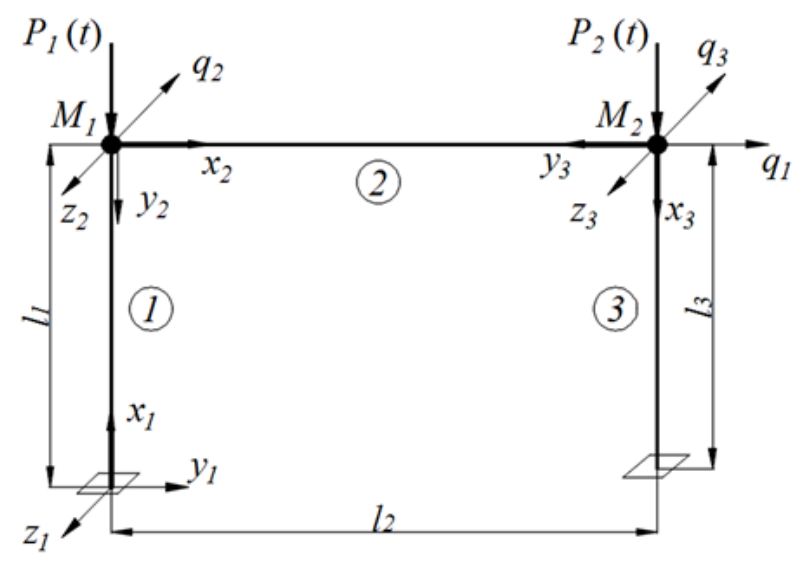

Fig.1. Frame scheme

The drawing shows the axes of the local coordinate systems $x_{k}, y_{k}, z_{k}(k=1,2,3)$ on each of the frame rods. Material point system $M_{1}, M_{2}$ has three degrees of freedom. They correspond to the axes of the generalized coordinate system $q_{1} q_{2} q_{3}$. Construction parameters: $l_{1}=l_{3}=6 \mathrm{~m}, l_{2}=10 \mathrm{~m}$. Material point masses: $m_{1}=m_{2}=50 \mathrm{~T}$. Bar cross-section dimensions (Fig. 2): $b=0.3 m, h=0.5 m, \delta_{1}=0.01 m, \delta_{2}=0.02 m$. Steel modulus of elasticity $E=2 \cdot 10^{5} \mathrm{MPa}$, shear modulus $G=0.8 \cdot 10^{5} \mathrm{MPa}$. 


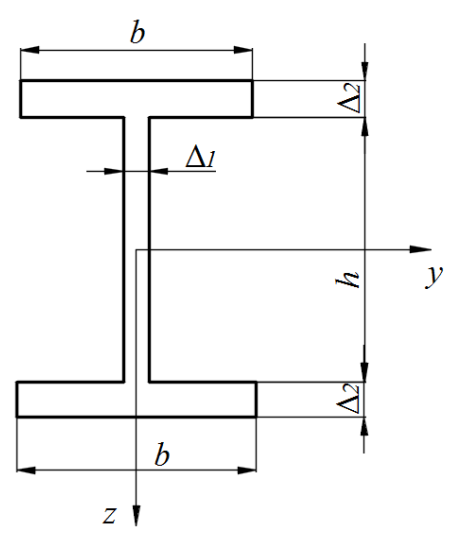

Fig. 2. Cross-section of frame rods

To build functions $\Phi_{i}(s)(i=1,2,3)$ we use the boundary element method [10]. We apply to the point $M_{1}$ force $\boldsymbol{F}_{1}\left(F_{1}=1 \kappa H\right)$ in the direction of the axis $q_{1}$. Fig. 3 schematically depicts the deformed state of the frame caused by the action of this force.

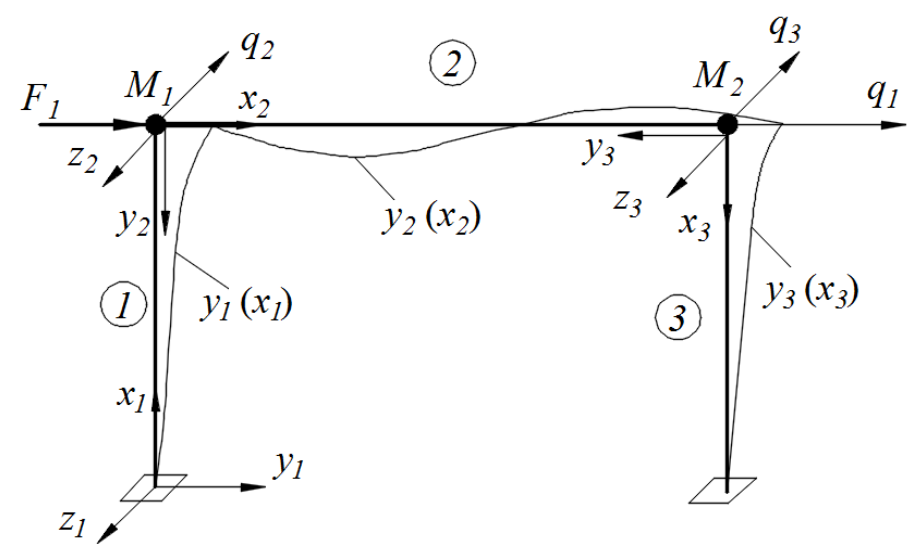

Fig. 3. Deformed state of the frame under the action of force $F_{1}$

Analytical expressions of functions $y_{1}\left(x_{1}\right), y_{2}\left(x_{2}\right), y_{3}\left(x_{3}\right)$ have the following form:

$$
\begin{aligned}
& y_{1}\left(x_{1}\right)=1.73676 \cdot 10^{-4} x_{1}-2.14557 \cdot 10^{-5} x_{1}^{3} ; \\
& y_{2}\left(x_{2}\right)=1.2758 \cdot 10^{-4} x_{2}-6.35216 \cdot 10^{-5} x_{2}^{2}+5.94676 \cdot 10^{-6} x_{2}^{3} \\
& y_{3}\left(x_{3}\right)=-1.65993 \cdot 10^{-3}+2.53013 \cdot 10^{-4} x_{3}+1.84731 \cdot 10^{-4} x_{3}^{2}-3.60596 \cdot 10^{-5} x_{3}^{3} .
\end{aligned}
$$

Notice, that $z_{i}\left(x_{i}\right)=0, \Theta_{i}\left(x_{i}\right)=0(i=1,2,3)$. Thus, the components of the function $\Phi_{1}(s)$ are presented as follows:

$$
\begin{aligned}
& \Phi_{1,1}(s)=y_{1}(s) \text { at } s \leq l_{1} ; \\
& \Phi_{1,1}(s)=y_{2}\left(s-l_{1}\right) \text { at } l_{1}<s \leq l_{1}+l_{2} ; \\
& \Phi_{1,1}(s)=y_{3}\left(s-l_{1}-l_{2}\right) \text { at } s>l_{1}+l_{2} \\
& \Phi_{1,2}(s)=\Phi_{1,3}(s)=0 \text { at all } s .
\end{aligned}
$$

We apply to the point $M_{1}$ force $\left(F_{2}=1 \kappa H\right)$ in the direction of the axis $q_{2}$. Fig. 4 shows the deformed state of the frame caused by this force. 


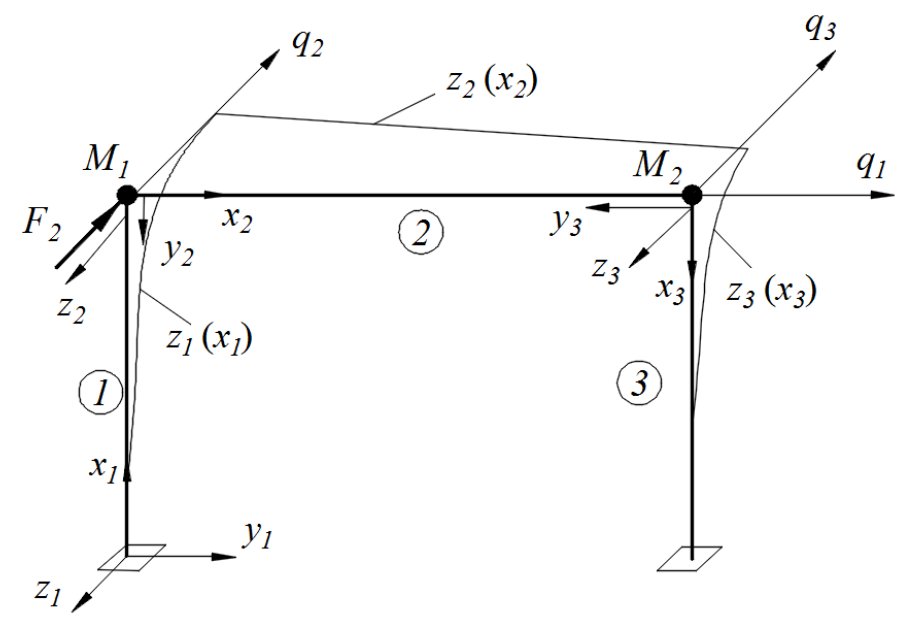

Fig. 4. Deformed state of the frame under the action of force $F_{2}$

Analytical expressions of functions $z_{i}\left(x_{i}\right), \psi_{i}\left(x_{i}\right)(i=1,2,3)$ have the following form:

$$
\begin{aligned}
& z_{1}\left(x_{1}\right)=-1.96667 \cdot 10^{-3} \cdot x_{1}^{2}+1.64014 \cdot 10^{-4} \cdot x_{1}^{3} ; \\
& \Theta_{1}\left(x_{1}\right)=3.14744 \cdot 10^{-4} x_{1} ; \\
& z_{2}\left(x_{2}\right)=-2.86665 \cdot 10^{-2}+1.57372 \cdot 10^{-3} x_{2}+2.67950 \cdot 10^{-4} x_{2}^{2}-2.33619 \cdot 10^{-5} x_{2}^{3} \\
& \Theta_{2}\left(x_{2}\right)=7.36569 \cdot 10^{-3}-1.43481 \cdot 10^{-4} x_{2} ; \\
& z_{3}\left(x_{3}\right)=-1.08878 \cdot 10^{-2}+6.21784 \cdot 10^{-3} x_{3}-4.93534 \cdot 10^{-4} x_{3}^{2}-2.33692 \cdot 10^{-5} x_{3}^{3} \\
& \Theta_{3}\left(x_{3}\right)=-1.37543 \cdot 10^{-3}+3.43858 \cdot 10^{-4} x_{3},
\end{aligned}
$$

wherein $y_{i}\left(x_{i}\right)=0(i=1,2,3)$.

We now apply to the point $M_{2}$ the force $\boldsymbol{F}_{3}\left(F_{3}=1 \kappa H\right)$ in the direction of the axis $q_{3}$. The deformed state of the frame caused by this force is shown in Fig. 4.

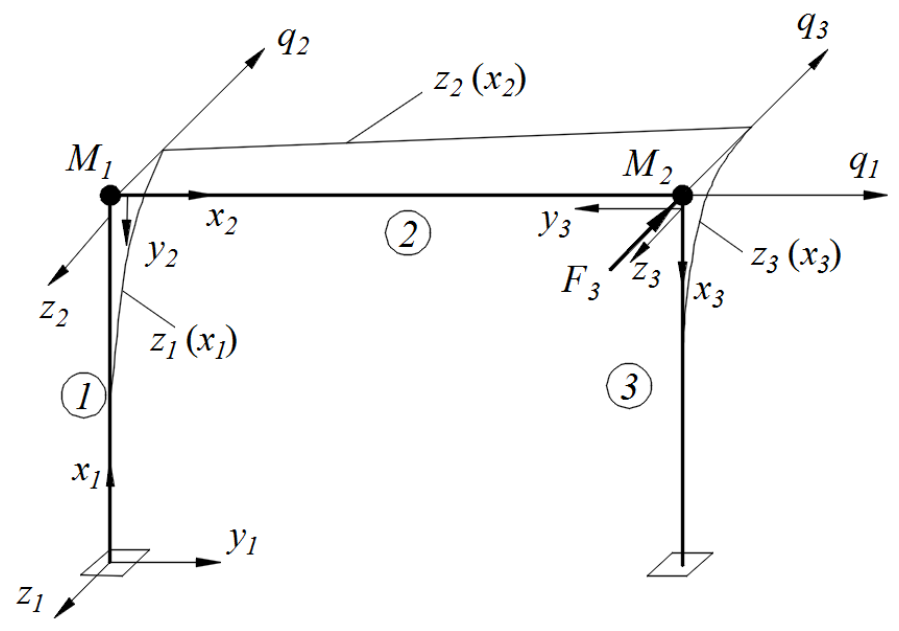

Fig. 4. Deformed state of the frame under the action of force $F_{3}$

Analytical expressions of functions $z_{i}\left(x_{i}\right), \Theta_{i}\left(x_{i}\right)(i=1,2,3)$ :

$$
\begin{aligned}
& z_{1}\left(x_{1}\right)=-8.42278 \cdot 10^{-4} x_{1}^{2}+2.57682 \cdot 10^{-5} \cdot x_{1}^{3}, \Theta_{1}\left(x_{1}\right)=-3.63105 \cdot 10^{-4} x_{1} \\
& z_{2}\left(x_{2}\right)=-1.78359 \cdot 10^{-2}-1.81553 \cdot 10^{-3} x_{2}-3.09121 \cdot 10^{-4} x_{2}^{2}+2.57601 \cdot 10^{-5} x_{2}^{3}
\end{aligned}
$$




$$
\begin{aligned}
& \Theta_{2}\left(x_{2}\right)=6.49016 \cdot 10^{-3}+1.32498 \cdot 10^{4} x_{2} ; \\
& z_{3}\left(x_{3}\right)=-3.89547 \cdot 10^{-2}+7.55014 \cdot 10^{-3} x_{3}+4.55755 \cdot 10^{-4} x_{3}^{2}-1.61615 \cdot 10^{-4} x_{3}^{3} ; \\
& \Theta_{3}\left(x_{3}\right)=1.81553 \cdot 10^{-3}-3.63105 \cdot 10^{-4} x_{3}, y_{i}\left(x_{i}\right)=0 \quad(i=1,2,3) .
\end{aligned}
$$

Function components $\boldsymbol{\Phi}_{k}(s)(k=2,3)$ are presented as follows:

$$
\begin{aligned}
& \Phi_{k, 1}(s)=0 \text { at all } s \\
& \Phi_{k, 2}(s)=z_{1}(s), \Phi_{k, 3}(s)=\Theta_{1}(s) \text { at } s \leq l_{1} ; \\
& \Phi_{k, 2}(s)=z_{2}\left(s-l_{1}\right), \Phi_{k, 3}(s)=\Theta_{2}\left(s-l_{1}\right) \text { at } l_{1}<s \leq l_{1}+l_{2} ; \\
& \Phi_{k, 2}(s)=z_{3}\left(s-l_{1}-l_{2}\right), \Phi_{k, 3}(s)=\Theta_{3}\left(s-l_{1}-l_{2}\right) \text { at } s>l_{1}+l_{2} .
\end{aligned}
$$

Next, we proceed to the definition of the elements of the matrices $\boldsymbol{F}, \boldsymbol{R}$ and $\boldsymbol{S}$, using formulas (7a), (9a), (15a). Solving equation (19), we find the frequencies of free vibrations of the frame with a system of weights loaded with longitudinal constant forces $P_{0, j}\left(P_{0, j}\right.$ are cargo weights $\left.M_{j}, j=1,2\right)$. Then, using (21), we construct the boundaries of the main domains of instability (Fig. 5).

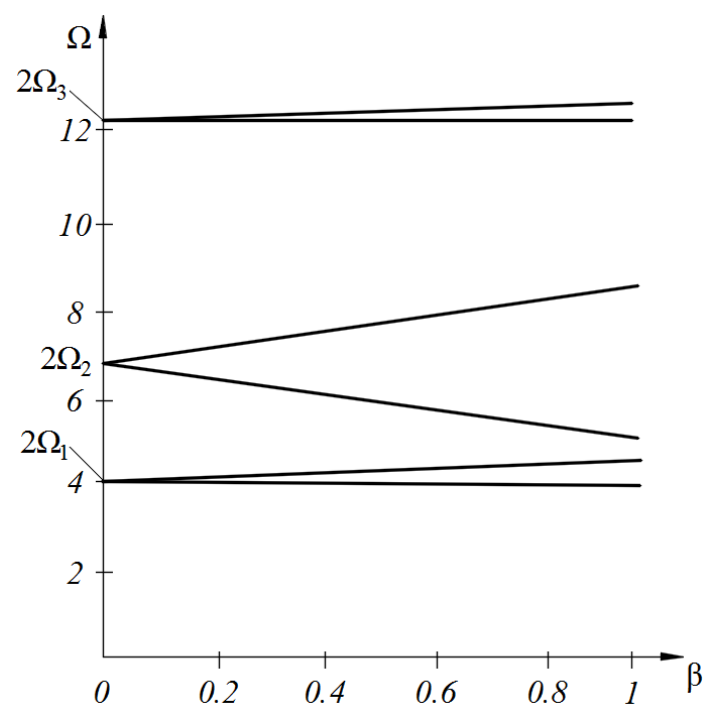

Fig. 5. The main regions of instability of the frame

\section{DISCUSSION OF RESEARCH RESULTS}

When designing buildings and structures, it is necessary to take into account the possibility of the occurrence of resonances between the dynamic loads acting on the structure, caused by seismic and industrial influences, and free vibrations of the structure. But besides the usual resonances, it is necessary to take into account the parametric resonances associated with the frequencies of the variable longitudinal forces created by the indicated dynamic influences. For this, domains of dynamic instability should be constructed in the space of these parameters. When these parameters enter into the domains, the appearance and buildup of transverse vibrations of structural elements is observed, i.e. the phenomenon of dynamic stability loss occurs.

\section{CONCLUSIONS}

The article proposes a method for constructing domains of dynamic instability for a structure in the form of a steel frame. When the parameters enter into these domains, the 
the emergence of spatial vibrations of the structure is observed.

\section{References}

1. Belyaev, N. M. (1924). Ustoychivost prizmaticheskikh sterzhney pod deystviem peremennykh prodolnykh sil. [Stability of prismatic rods under the action of variable longitudinal forces]. Ingenerniye soorugeniya i stroitelnaya mehanika. Moskva. Put'. 149-167. [in Russian].

2. Krylov, N. M., Bogolyubov, N. N. (1935). Issledovanie yavleniy rezonansa pri poperechnykh kolebaniyakh sterzhney, nakhodyashchikhsya pod vozdeystviem periodicheskikh normalnykh sil, prilozhennykh $\mathrm{k}$ odnomu iz kontsov sterzhnya [Investigation of resonance phenomena during transverse vibrations of rods under the influence of periodic normal forces applied to one of the ends of the rod]. Issledovaniye kolebaniy konstruktsiy. Kharkov-Kiyev. NTI. 25-42. [in Russian].

3. Mettler, E. (1940). Biegeschwingungen eines Stabes unter pulsierender Axiallast. Mitt. Forsch. Anst.Gffii-Konzern. 8. 17-39.

4. Chelomey, V. N. (1939). Dinamicheskaya ustoychivost elementov aviatsionnykh konstruktsiy. [Dynamic stability of elements of aircraft structures]. Moskva. Aeroflot. [in Russian].

5. Bolotin, V. V. (1956). Dinamicheskaya ustoychivost uprugikh system. [Dynamic stability of elastic systems]. Moskva. Gosudarstvennoe izdatelstvo tekhniko-teoreticheskoy literatury. [in Russian].

6. Bolotin, V. V. (1956). Voprosy obshchey teorii uprugoy ustoychivosti. [Questions of the general theory of elastic stability]. Prikladnaya matematika $i$ mekhanika. T. 20. V. 5. 561-577. [in Russian].

7. Gotsulyak, Ye. O., Dekhtyaryuk, Ye. S., Lukyanchenko, O. D., Borysehko, V. H. (2005). Pobudova redukovanikh rivnyan dinamichnoï stiykosti ploskoï formi zginu pruzhnikh system. [Derivation of dynamic stability reduced equations of elastic systems plane bending modes]. Opir materialiv i teoriya sporud. K.: KNUBA. 77. 65-77. [in Ukranian].

8. Lukyanchenko O. D., Vorona Yu. V., Kostina O. V. (2014). Parametric resonance in statically indeterminate frames. Determination of materials and theory of construction. K.: KNUBA. 93. 91-99.

9. Nikolaenko, N.A., Nazarov, Yu.P. (1988). Dinamika i seysmostoykost sooruzheniy. [Dynamics and seismic resistance of structures]. Moskva. Stroyizdat. [in Russian].

10.Daschenko, A. F., Kolomiyets, L. V., Orobey, V. F., Surianinov, N. G. (2010). Chislennoanaliticheskiy metod granichnykh elementov. [Numerical-analytical boundary elements method]. Odessa. VMV. [in Russian].

\section{Література}

1. Беляев Н. М. Устойчивость призматических стержней под действием переменных продольных сил. Инженерные сооружения и строительная механика. М.: Путь, 1924. С. $149-167$.

2. Крылов Н. М., Боголюбов Н. Н. Исследование явлений резонанса при поперечных колебаниях стержней, находящихся под воздействием периодических нормальных сил, приложенных к одному из концов стержня. В кн. Исследование колебания конструкций. Сб. статей, Харьков-Киев. НТИ. С. 25-42.

3. Mettler E. Biegeschwingungen eines Stabes unter pulsierender Axiallast. Mitt. Forsch., Anst.GffiiKonzern. 1940. 8. P. 17-39.

4. Челомей В. Н. Динамическая устойчивость элементов авиационных конструкций. Москва. Аэрофлот, 1939. $80 \mathrm{c}$.

5. Болотин В. В. Динамическая устойчивость упругих систем. Москва. Государственное издательство технико-теоретической литературы, 1956. 600 с.

6. Болотин В. В. Вопросы общей теории упругой устойчивости. Прикладная математика и механика, 1956. Т. 20. Вып. 5. С. 561-577.

7. Гоцуляк Є. О., Дехтярюк Є. С., Лук'янченко О. О., Борисенко В. Г. Побудова редукованих рівнянь динамічної стійкості плоскої форми згину пружних систем. Опір матеріалів і теорія споруд. К.: КНУБА, 2005. Вип.77. С. 65-77.

8. Lukyanchenko O. D., Vorona Yu. V., Kostina O. V. Parametric resonance in statically indeterminate frames. Determination of materials and theory of construction. K.: KNUBA. 2014. V. 93. P. 91-99. 
9. Николаенко Н. А., Назаров Ю. П. Динамика и сейсмостойкость сооружений. М.: Стройиздат, 1988. $308 \mathrm{c}$

10.Дащенко А. Ф., Коломиец Л. В., Оробей В. Ф., Сурьянинов Н. Г. Численно-аналитический метод граничных элементов. Одесса: ВМВ, 2010. Т.1 - 415 с., Т. 2 - 510 с.

\section{Фомін Володимир Михайлович}

Одеська державна академія будівництва та архітектури, д.т.н., професор

вул. Дідріхсона, 4, Одеса, Україна 65029

vmfomin39@gmail.com

ORCID: 0000-0003-4814-6415

Фоміна Інна Петрівна

Одеська державна академія будівництва та архітектури, старший викладач

вул. Дідріхсона, 4, Одеса, Україна 65029

fomina@ogasa.org.ua

ORCID: 0000-0001-7366-1537

For references:

Fomin V. Fomina I. (2021). Spatial problems of dynamic stability of frame structures. Mechanics and Mathematical Methods. 3 (2). 40-51.

Для посилань:

Фомін В. М., Фоміна І. П. Просторові задачі динамічної стабільності каркасних конструкцій. Механіка та математичні методи, 2021. Т. 3. №. 2. С. 40-51. 